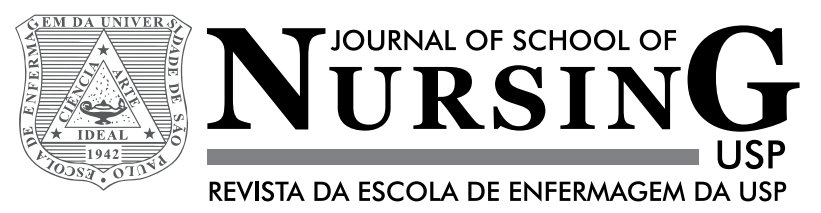

\title{
Distance education in neonatal nursing scenarios: a systematic review
}

\section{Educação a distância no cenário da enfermagem neonatal: revisão sistemática Educación a distancia en el escenario de la enfermería neonatal: revisión sistemática}

Laís Machado Freire ${ }^{1}$, Mariane Andreza de Paula ${ }^{1}$, Elysangela Dittz Duarte ${ }^{2}$, Mariana Bueno $^{3}$

${ }^{1}$ Undergraduate Student, School of Nursing,
Universidade Federal de Minas Gerais, Belo
Horizonte, MG, Brazil.
${ }^{2}$ Adjunct Professor, Universidade Federal de
Minas Gerais, Belo Horizonte, MG, Brazil.
${ }^{3}$ Doctorate Professor, School of Nursing,
Universidade de São Paulo, São Paulo, SP, Brazil.

Corresponding author:

Mariana Bueno

Av. Dr. Enéas de Carvalho de Aguiar, 419 -

Cerqueira Cesar

CEP 05403-000 - São Paulo, SP, Brazil

mariana.bueno@usp.br

\section{ABSTRACT}

Objective: Identify resources that support learning mediated by technology in the field of neonatal nursing. Method: Systematic review with searches conducted in MEDLINE, LILACS and SciELO. Titles and abstracts were independently evaluated by two experts. Results: Of the 2,051 references, 203 full-text articles were analyzed, resulting in the inclusion of nine studies on semiotics and semiology, cardiopulmonary resuscitation, general aspects of neonatal care, diagnostic reasoning and assessment of pain. Only two articles addressed the development of educational strategies and seven papers described the assessment of these strategies by experts and/or users. Conclusion: Distance education is an important resource for education, and its improvement and updating, and it particularly adds advantages for neonatal nursing by approximating teaching and real-life situations and by minimizing the exposure of newborns for teaching purposes. The lack of educational initiatives mediated by technology suggests the need for the development, evaluation and dissemination of educational resources focused on nursing care of newborns and their families.

\section{DESCRIPTORS}

Neonatal Nursing; Education, Nursing; Education, Distance; Educational Technology; Review. 


\section{INTRODUCTION}

Distance education (DE) consists of a systematic teaching-learning process, which allows individual or group study through the use of technologies in which teachers and students are not physically at the same geographical space at the same time ${ }^{(1-2)}$. Several instruments or media may be used to mediate DE in the fields of education, training, improvement and professional development, such as correspondence, radio, television, CD-ROMs, software, and more recently, the World Wide Web. It is believed that through DE it is possible to exploit the potential of the subjects involved, establish multidirectional communication, new relationships and interactions, exchange experiences and share knowledge ${ }^{(1)}$. From this perspective, it puts the student as the central character and the teacher as a facilitator of the learning process.

Some of the advantages of DE are temporal flexibility, spatial decentralization, collaboration and communication between users, increased user confidence in learning, development of computer-related skills, active and directed by the user learning process, creating safe environments, satisfying different learning needs and reducing teaching time $^{(2-3)}$.

Currently, it is considered as an important strategy for postsecondary education and professionals. This is because the proper use of communication technologies and information, among others, is mainly aimed towards graduating adults at the undergraduate, post-graduate, and extension levels, as well as sequential courses and continuing education $^{(2)}$, and is recommended by the new curriculum guidelines of higher education ${ }^{(4)}$.

It is worth noting that it is necessary to adapt the education strategies to the abilities and preferences of the target audience, in this case especially for nursing graduates and professional nurses. There are currently two generations which are predominant in the labor market and in higher education institutions, the $\mathrm{X}$ and $\mathrm{Y}$ generations. Generation $\mathrm{X}$ is represented by individuals born between 1965 and 1980. They are self-confident, realistic and search for balance between work, leisure and family; they feel comfortable with the use of technology, accept changes easily, are able to develop multiple tasks and value knowledge and continuous learning; educational preferences include audiovisual material or online and questioning mediated by the use of synthetic support materials ${ }^{(5)}$. On the other hand, Generation Y is composed of people born from 1980 to 2001, they are dynamic, safe, optimistic and goal-oriented; they respond well to changes and appreciate continued learning which can be implemented in their practice; they prefer ways of learning that involve the use of technology, focusing on doing the work, on collaborating, the use of case studies and simulation ${ }^{(5)}$.

Particularly in the nursing setting there is an increasing rate of educational strategies mediated by technology, although still without a significant quantitative value in relation to traditional courses ${ }^{(2)}$. Nursing has been undergoing continuous changes and it can be emphasized that technological and scientific advances have been incorporated in an accelerated fashion, especially for the practice of neonatal nursing. In this sense, the use of distance education strategies can promote continuing and current education for students and professionals because it is a dynamic process that allows frequent modifications and updates. Additionally, DE addresses the teaching preferences of Generations $\mathrm{X}$ and $\mathrm{Y}$, corresponding to professionals that work or will work in clinical practice. Finally, this teaching strategy adds specific advantages such as reducing the exposure of the newborn to teaching, plus the ability to recreate situations and environments containing components of the real contextual care. Therefore, it was considered necessary to identify resources available in the scientific literature that support education mediated by technology in neonatal nursing.

This study aimed to identify resources that support education strategies mediated by technology in neonatal nursing.

\section{METHOD}

This is a systematic review of the literature based on recommendations by the Cochrane Collaboration ${ }^{(6)}$.

\section{Search Strategy}

The following electronic databases were consulted: Medical Literature Analysis and Retrieval System Online (MEDLINE), Latin American and Caribbean Health Sciences Literature (LILACS) and Scientific Electronic Library Online - Brazil (SciELO). Such databases were selected for encompassing a broad spectrum of national and international publications, and include an extensive number of indexed journals.

Initially, there was a search conducted on the structured vocabulary of DeCS - Descriptors in Health Sciences and in MeSH - Medical Subject Headings, in order to identify the appropriate search terms and index these controlled vocabularies. Selected terms were: "Informática em enfermagem"/"Nursing informatics," "Educação em enfermagem"/"Education, nursing," "Tecnologia educacional"/“Educational technology," "Educação a distância"/"Education, distance," "Enfermagem neonatal"/"Neonatal nursing" and "Recém-nascido"/“Infant, newborn." The terms were combined in pairs, as described in Table 1 . The searches were conducted in January 2014, without restrictions on time, location or language of publication.

Chart 1 - Description of the search strategy used - Belo Horizonte, MG, Brazil, 2014.

\begin{tabular}{|c|c|c|}
\hline \multirow{4}{*}{$\begin{array}{l}\text { "Enfermagem neonatal"/ } \\
\text { "Neonatal nursing" }\end{array}$} & \multirow{4}{*}{ “AND” } & $\begin{array}{l}\text { "Informática em enfermagem"/ } \\
\text { "Nursing informatics" }\end{array}$ \\
\hline & & $\begin{array}{l}\text { "Educação em enfermagem"/ } \\
\text { "Education, nursing" }\end{array}$ \\
\hline & & $\begin{array}{l}\text { "Tecnologia educacional"/ } \\
\text { "Educational technology" }\end{array}$ \\
\hline & & $\begin{array}{l}\text { "Educação a distância"/ } \\
\text { "Education, distance" }\end{array}$ \\
\hline
\end{tabular}

continued.. 


\begin{tabular}{|c|c|c|}
\hline \multirow{4}{*}{$\begin{array}{l}\text { "Recém-nascido"/ } \\
\text { "Infant, newborn" }\end{array}$} & \multirow{4}{*}{ "AND" } & $\begin{array}{l}\text { "Informática em enfermagem"/ } \\
\text { "Nursing informatics" }\end{array}$ \\
\hline & & $\begin{array}{l}\text { "Educação em enfermagem"/ } \\
\text { "Education, nursing" }\end{array}$ \\
\hline & & $\begin{array}{l}\text { "Tecnologia educacional"/ } \\
\text { "Educational technology" }\end{array}$ \\
\hline & & $\begin{array}{l}\text { "Educação a distância"/ } \\
\text { "Educcation, distance" }\end{array}$ \\
\hline
\end{tabular}

\section{Abstracts SCREenInG}

Original studies that dealt with DE strategies in the context of neonatal nursing were included. Descriptions of teaching strategies developed in the area of neonatal nursing, as well as publications that addressed the evaluation of these strategies (either from the perspective of experts or from the perspective of users) were considered. Exclusions occurred in the case of papers that focused on face-to-face education strategies, such as classes, workshops, seminars, and realistic or laboratory simulation, among others. Publications on teaching strategies aimed to parents and families, teaching strategies unrelated to neonatology, descriptions and reflections on nursing education curricula, descriptions and qualitative reflections on nursing education, and studies that did not address the issue of this review were also excluded.

Considering the variety of methodologies that can be adopted for the development and evaluation of DE strategies, it was impossible to establish one specific study design to be attributed as inclusion criteria. Furthermore, titles and abstracts were initially evaluated by two reviewers independently. Next, two experts also independently evaluated full-text articles for the final selection of studies that would be included.

\section{EXTRACTION AND SUMMARY OF RESULTS}

The following data were extracted from the included studies: year of publication, research site/location, proposed topics for distance education, purpose of the study, subjects involved (number and role), target audience, main results and conclusions. From these data, the results of this review are presented descriptively.

\section{RESULTS}

A total of 2,051 references were retrieved, being 2,006 from MEDLINE, 37 from LILACS and eight from ScieloBrazil (Figure 1). After the initial evaluation, 221 duplicates were identified and excluded (207 MEDLINE, 10 in LILACS and four in SciELO). Based on the analysis of 1,830 titles and abstracts (the latter when available), 203 references were selected for analysis. Of these, 35 were not located and 159 were excluded, as per the exclusion reasons listed in Figure 1. Finally, nine articles were included (Figure 1).

\begin{tabular}{|c|c|}
\hline \multicolumn{2}{|r|}{ Total retrieved references $(\mathrm{n}=2.051)$} \\
\hline & Duplicates excluded $(\mathrm{n}=221)$ \\
\hline \multicolumn{2}{|r|}{ Identification of unique references $(n=1.830)$} \\
\hline & References excluded after title and abstract analysis $(\mathrm{n}=1.627)$ \\
\hline \multicolumn{2}{|r|}{ References considered relevant $(n=203)$} \\
\hline \begin{tabular}{|} 
\\
\end{tabular} & $\begin{array}{l}\text { References excluded of review }(n=194) \text { : } \\
\text { Classroom teaching }(n=67) \\
\text { Description of change or curriculum updating }(n=13) \\
\text { Editorial, letter or brief communication }(n=22) \\
\text { Education mediated by written material }(n=2) \\
\text { Education for family and / or patients }(n=12) \\
\text { Qualitative studies on education }(n=3) \\
\text { Strategies not related to neonatal }(n=4) \\
\text { Description of protocols or guidelines }(n=8) \\
\text { Literature review or reflection }(n=13) \\
\text { Development of a model for simulation }(n=1) \\
\text { Description of education strategy in development }(n=1) \\
\text { Does not deal with education strategies }(n=13) \\
\text { Articles not entirely located }(n=35)\end{array}$ \\
\hline \multicolumn{2}{|r|}{ References included in the review $(n=9)$} \\
\hline
\end{tabular}

Figure 1 - Study selection process for the systematic review Belo Horizonte, MG, Brazil, 2014.

Of the included studies, seven were developed in Brazil and linked to higher education institutions of the state of São Paulo. One study was conducted in Canada, and one study in India. In two publications, the authors only described the development of distance education strategy, while in seven articles, the evaluation processes of teaching strategies were described either by experts, or by users.

The topics addressed involved the semiotics and semiology of newborns (four articles) $)^{(7-10)}$, neonatal resuscitation (two articles) ${ }^{(11-12)}$, general topics of neonatal care (one article $)^{(13)}$, diagnostic reasoning in nursing (one article) $)^{(14)}$ and assessment of pain (one article) ${ }^{(15)}$. Table 2 below presents the main characteristics of the studies included in this review, as well as its main findings.

\section{DISCUSSION}

Considering the high number of unique references analyzed for the present systematic review $(1,830)$, a very small number of publications met the inclusion criteria (nine articles, $0.5 \%)$. Note that this percentage can be explained by the selection criteria of the studies for inclusion, considering the use of educational strategies mediated by technology aimed at neonatal nursing.

It is also important to note the possibility of subjects and courses mediated by technology targeted to students and nursing professionals which focus on neonatal nursing not being described in a systematic manner in the literature; this did not allow for some to be found and therefore were not included in this systematic review.

Chart 2 - Characteristics of studies included in the systematic review - Belo Horizonte, MG, Brazil, 2014.

\begin{tabular}{|l|l|l|l|l|}
\hline $\begin{array}{l}\text { Main author/ } \\
\text { year }\end{array}$ & Country & $\begin{array}{l}\text { Education initiative development/ } \\
\text { assessment }\end{array}$ & $\begin{array}{l}\text { Number of } \\
\text { subjects }\end{array}$ & DE characteristics and main findings \\
\hline $\begin{array}{l}\text { Fonseca, } \\
2013^{(10)}\end{array}$ & Brazil & $\begin{array}{l}\text { Validation of content and appear- } \\
\text { ance of the virtual learning object } \\
\text { "Semiotics and Semiology of the } \\
\text { Preterm Newborn" by users }\end{array}$ & $\begin{array}{l}57 \text { nursing } \\
\text { under- } \\
\text { graduate } \\
\text { students }\end{array}$ & $\begin{array}{l}\text { The overall impression was highly satisfactory and the object } \\
\text { content was considered important or very important. The } \\
\text { simulations were considered relevant by the vast majority of } \\
\text { students. }\end{array}$ \\
\hline
\end{tabular}

continued... 


\begin{tabular}{|c|c|c|c|c|}
\hline $\begin{array}{l}\text { Main author/ } \\
\text { year }\end{array}$ & Country & $\begin{array}{l}\text { Education initiative development/ } \\
\text { assessment }\end{array}$ & $\begin{array}{l}\text { Number of } \\
\text { subjects }\end{array}$ & DE characteristics and main findings \\
\hline $\begin{array}{l}\text { Rodrigues, } \\
2013^{(12)}\end{array}$ & Brazil & $\begin{array}{l}\text { Development of virtual learning } \\
\text { object for cardiopulmonary resus- } \\
\text { citation teaching in neonatology } \\
\text { and assessment by experts and } \\
\text { users }\end{array}$ & $\begin{array}{l}2 \text { special- } \\
\text { ists in IT, } \\
3 \text { nursing } \\
\text { under- } \\
\text { graduate } \\
\text { students, } 3 \\
\text { nurses, } 1 \\
\text { doctor }\end{array}$ & $\begin{array}{l}\text { The methodology for creating the environment consisted of } \\
\text { five phases: analysis, design, development, assessment and } \\
\text { administration. The environment was considered intuitive, } \\
\text { visually pleasing, with good navigability and accessibility. } 37 \\
\text { items were evaluated by operating staff and } 43 \text { by students and } \\
\text { experts, which resulted in a total of } 457 \text { significant responses } \\
\text { and only six left unanswered. The environment was predomi- } \\
\text { nantly considered as excellent, a few aspects were considered } \\
\text { reasonable and only one was assessed as unsatisfactory. }\end{array}$ \\
\hline $\begin{array}{l}\text { Fonseca, } \\
2012^{(9)}\end{array}$ & Brazil & $\begin{array}{l}\text { Semantic evaluation of the virtual } \\
\text { learning object "Semiotics and Se- } \\
\text { miology of the Preterm Newborn" } \\
\text { by users }\end{array}$ & $\begin{array}{l}51 \text { nursing } \\
\text { under- } \\
\text { graduate } \\
\text { students }\end{array}$ & $\begin{array}{l}\text { The students answered a questionnaire related to the software, } \\
\text { pointed out technical errors and considered the multimedia } \\
\text { resources (text, video, pictures, simulations) as a differential } \\
\text { object. The errors were corrected and improvements and ad- } \\
\text { justments were implemented based on the recommendations. }\end{array}$ \\
\hline $\begin{array}{l}\text { Thukral, } \\
2012^{(13)}\end{array}$ & India & $\begin{array}{l}\text { Development of the virtual } \\
\text { learning object "On-line Neo- } \\
\text { natal Training and Orientation } \\
\text { Programme in India (ONTOP-IN)" } \\
\text { and evaluation by users }\end{array}$ & 98 nurses & $\begin{array}{l}\text { The themes addressed in the program included: feeding of } \\
\text { healthy newborn, alternative feeding methods, kangaroo } \\
\text { mother care, hypothermia, care of the newborn at birth, } \\
\text { routine care, basic aspects of resuscitation, examination of } \\
\text { the newborn, management of low birth weight neonate and } \\
\text { general scenario of newborn health in India. Pre- and post-test } \\
\text { with } 25 \text { questions indicated: significant increase of knowledge } \\
\text { and skill scores (mean difference } 6.4(95 \% \mathrm{Cl}, 5.6 \text { to } 7.17) \text {, } \\
\text { mean difference } 15.4 \text { ( } 95 \% \mathrm{Cl}, 12.7 \text { to } 18.1) \text {, respectively), and } \\
\mathrm{p}<0.001 \text { for both comparisons. The initiative was positively } \\
\text { evaluated by all users. }\end{array}$ \\
\hline Góes, $2011^{(14)}$ & Brazil & $\begin{array}{l}\text { Validation of content and appear- } \\
\text { ance of the virtual learning object } \\
\text { "Diagnostic Reasoning in Nursing } \\
\text { Applied to Preterm Newborns" by } \\
\text { specialists }\end{array}$ & $\begin{array}{l}12 \text { spe- } \\
\text { cialists, } \\
\text { graduates } \\
\text { from IT or } \\
\text { correlated } \\
\text { areas, } \\
17 \text { nurses, } \\
14 \text { nursing } \\
\text { professors }\end{array}$ & $\begin{array}{l}\text { The virtual object has a modular structure with theoretical con- } \\
\text { tent on nursing diagnosis, and a module for teaching diagnoses } \\
\text { from the Risner rationale and the NANDA taxonomy, and a } \\
\text { module that shows simulations for learning with seven clini- } \\
\text { cal cases of premature infants, totaling } 72 \text { nursing diagnoses. } \\
\text { All items (presentation, organization, usability and overall } \\
\text { impression) were evaluated positively by more than } 80 \% \text { of } \\
\text { the evaluators, except the informational density criterion in the } \\
\text { evaluation by IT professionals. }\end{array}$ \\
\hline $\begin{array}{l}\text { Gonçalves, } \\
2010^{(11)}\end{array}$ & Brazil & $\begin{array}{l}\text { Development of the virtual learn- } \\
\text { ing object "Cardiopulmonary } \\
\text { Resuscitation for the Neonatal } \\
\text { Care" }\end{array}$ & $\begin{array}{l}\text { Not ap- } \\
\text { plicable }\end{array}$ & $\begin{array}{l}\text { The object development followed the cyclical and interac- } \\
\text { tive stages of conception and planning, development and } \\
\text { implementation. Themes addressed were: fundamentals of } \\
\text { anatomy and cardiac physiology; risk factors for the occur- } \\
\text { rence of cardiac arrest; nursing care planning; medications } \\
\text { used in cardiopulmonary arrest; and cardiac arrest care. The } \\
\text { initial evaluation of navigation, as well as the evaluation of } \\
\text { the content by the researchers indicated that the proposal was } \\
\text { characterized as innovative in order to contribute to the theme } \\
\text { of nursing student education. }\end{array}$ \\
\hline $\begin{array}{l}\text { Fonseca, } \\
2009^{(7)}\end{array}$ & Brazil & $\begin{array}{l}\text { Development of the virtual learn- } \\
\text { ing object "Semiotics and Semiol- } \\
\text { ogy of the Preterm Newborn" }\end{array}$ & $\begin{array}{l}\text { Not ap- } \\
\text { plicable }\end{array}$ & $\begin{array}{l}\text { The development of the object was carried out in four phases } \\
\text { (scope, planning, production and implementation) and resulted } \\
\text { in a software consisting of the following contents: (1) presen- } \\
\text { tation, justification, objective and list of abbreviations, (2) } \\
\text { semiotics (theoretical concepts and practicing of inspection } \\
\text { techniques, palpation, percussion and auscultation used in } \\
\text { the clinical evaluation of premature infants), (3) semiology } \\
\text { (concepts, history, context and types of evaluation - at birth, } \\
\text { transition and systematic, with the latter being formed by basic } \\
\text { human needs) (4) simulations (multiple-choice questions with } \\
\text { feedback). }\end{array}$ \\
\hline $\begin{array}{l}\text { Fonseca, } \\
2008^{(8)}\end{array}$ & Brazil & $\begin{array}{l}\text { Evaluation of the virtual learning } \\
\text { object "Semiotics and Semiol- } \\
\text { ogy of the Preterm Newborn" by } \\
\text { specialists }\end{array}$ & $\begin{array}{l}5 \text { special- } \\
\text { ists in the } \\
\text { area of } \\
\text { technology, } \\
5 \text { nursing } \\
\text { professors, } \\
6 \text { nurses }\end{array}$ & $\begin{array}{l}\text { The object was considered good or very good for the follow- } \\
\text { ing items: response time, aesthetic and audiovisual adequacy, } \\
\text { appropriateness of the program, quality of the simulations. The } \\
\text { content was evaluated as good or very good by professors and } \\
\text { nurses. }\end{array}$ \\
\hline $\begin{array}{l}\text { Gibbins, } \\
2007^{(15)}\end{array}$ & Canada & $\begin{array}{l}\text { Satisfaction and applicability } \\
\text { evaluation of the virtual learning } \\
\text { object on the Premature Infant } \\
\text { Pain Profile (PIPP) by users }\end{array}$ & $\begin{array}{l}68 \text { health } \\
\text { profession- } \\
\text { als }\end{array}$ & $\begin{array}{l}\text { The object content included: training objectives; definition and } \\
\text { physiology of pain; pain assessment and measurement; physi- } \\
\text { ological and behavioral indicators of pain; PIPP components; } \\
\text { interpretation of PIPP scores; frequently asked questions about } \\
\text { PIPP. On the Likert scale (with maximum score of five points), } \\
\text { the average satisfaction was } 4.88( \pm 0.35) \text { points. Over } 95 \% \text { of } \\
\text { users felt they were very satisfied with the content and applica- } \\
\text { tion of software. } 90 \% \text { of participants considered the instruc- } \\
\text { tions and the navigation of the software clear and easy ( } 4.38 \pm \\
0.74) \text {, the acceptability of the software as a teaching method } \\
\text { was high }(4.88 \pm 0.31) \text {. }\end{array}$ \\
\hline
\end{tabular}


Learning methodologies mediated by technology are intended to replace the memory and the simple transfer of information and skills for the construction of knowledge from the experience of real or simulated situations of professional practice, stimulating the capabilities of critical and reflective analysis and learning ${ }^{(4)}$.

In a systematic review and meta-analysis published in the literature, 99 randomized clinical trials comparing education mediated by technology to traditional strategies were included ${ }^{(16)}$. The studies measured the education aimed at different age groups (from school to professional) and areas of knowledge. The results indicated better performance in learning for users participating in online learning or mixed strategies (combination of traditional teaching and mediated by technology) compared to users who participated in traditional strategies. However, the size of the effect found was small (effect size: $+0.24, p<0.01$ ). When comparing the mixed strategies to teaching purely online, the results were favorable for mixed strategies (effect size: $+0.14, p<0.05$ ). Better effectiveness of blended learning over traditional was also observed (effect size: $+0.35, p<0.001$ ).

The effects of an online course, an online course facilitated by an instructor and a classroom course mediated by an instructor offered to 1,661 nurses were compared ${ }^{(17)}$. There was no significant difference in learning and user's satisfaction between strategies. However, the online course had a better cost-effectiveness: USD $\$ 4.05$ per student for the online course and $\$ 59.35$ for classroom teaching mediated by an instructor.

In addition to advantages such as increased knowledge and cost-effectiveness, strategies mediated by technology can be considered as very important for neonatal nursing, both for training and for continuing education. This is because the use of simulated environments minimizes the exposure of newborns, reduces risks of clinical teaching, and bridges the gap between theory and academic and professional practice by providing situations that approach real context. In addition, it stimulates the digital inclusion of academics and professionals.

The publication of four articles related to semiotics and semiology of premature newborns software denotes the concern of the authors not only to development, but with the strength and the quality of this tool for neonatal nursing education. The methodological and descriptive studies address a very important theme for care practice. It is noteworthy that this initiative can be used for undergraduates and professionals involved in the neonatal care, which not only favors the training but also continuous education and updating knowledge.

With respect to neonatal resuscitation, this is a procedure to be performed by highly trained professionals. In undergraduate education, is little explored due to its complexity. In addition, updates and new evidence-based practices are often incorporated into neonatal care, which require the continuing education of professionals involved in the care. Thus, resources mediated by technology can be used to train students and professionals in the nursing field, with special emphasis on simulations that can contribute to clinical rationale and decision making.
The ONTOP-IN initiative favored the acquisition of knowledge and the development of clinical skills for neonatal care ${ }^{(13)}$. It is an initiative that covers general aspects of neonatal care and assists in continuing education of nurses. A training strategy for health professionals working in neonatal units was also developed at the national level, through the online course Atenção à Saúde do Recém-Nascido de Risco: Superando Pontos Críticos. This is a resultant partnership initiative between the Collaborating Centre for Prevention of Childhood Blindness of the Pan American Health Organization, the Instituto Fernandes Figueira/FIOCRUZ and the Telemedicine Discipline of the University of São Paulo. It consists of eight modules and has the following contents: supportive care, pain management, infection, nutrition, oxygen, retinopathy of prematurity and temperature. It appears as an extremely relevant initiative in the context of neonatal nursing, and studies to evaluate its impact on knowledge, skills and professional practice would certainly add value to the course.

Another study included in this review is the employment of distance education as a tool for simulation in the development of diagnostic reasoning in nursing. The establishment of nursing diagnoses is a step in the nursing process, the result of research and clinical rationale, and subsidizes the care planning so that satisfactory results are achieved. Therefore, the development of these skills in the context of neonatal nursing is crucial. In this sense, the use of the proposed software seems to favor the simulation of real situations for clinical rationale and construction of nursing diagnoses and specific care plans. It is important to emphasize the need for evaluation of this software from the perspective of professionals and undergraduate students in order to identify its usefulness for these users and its role in the acquisition of knowledge and skills.

Regarding neonatal pain, it is known that pain assessment is an essential step for its proper control. The theme is very little addressed in undergraduate courses, and even in specialization and continuing education services, the management of pain is only slightly systematized and effective in the neonatal care services. Therefore, the need for a fundamental strategy is apparent. In Brazil, the Neonatal Pain Assessment Program II is in its final development and evaluation process, and involves training students and health care professionals for the use of pain assessment tools for newborns in clinical practice ${ }^{(18)}$, being linked to the University of São Paulo and Federal University of Minas Gerais.

The observed heterogeneity among the included studies appears as the main limitation. This is because amongst the publications there were different topics addressed, as well as different methodologies for the development and evaluation of education strategies mediated by technology. Therefore, indicators of methodological quality of the included studies were not used. The wide variation in the outcomes described in the publications is also noteworthy, which prevented synthesis of the findings.

The results of this systematic review indicated that there are many issues to be addressed in neonatal care and the concern of the authors regarding the usefulness and quality 
of the teaching strategies was demonstrated in seven studies through the evaluation of these strategies by users and experts.

It is also worth noting the importance of exploring the acquisition of knowledge, the development of clinical skills and the usefulness of these strategies for users in different scenarios, for example in undergraduate courses, specialization and residence programs, and care scenarios such as rooming in units, intensive and semi-intensive neonatal units, and outpatient clinics, among others, in order to provide robust tools for teaching and updating knowledge.

The neonatal nursing field is extensive and highly specialized, and therefore many issues can be addressed in initiatives mediated by technology for teaching and professional development. Given the advantages presented in this review, it is suggested that teachers and researchers engaged in the development of new teaching strategies and teaching resources can contribute to the quality of care to newborns and their families. Strategies like ONTOP-IN and Atenção à Saúde do Recém-Nascido de Risco: Superando Pontos Críticos, for example, are essential as they present general aspects of neonatal care and are of particular importance in a coun- try like Brazil, with such a vast territorial area, and wide variations in resources and access to information in varying locations. Moreover, specific issues such as pain assessment and cardiopulmonary resuscitation are also successful examples of issues that can be better explored through education strategies mediated by technology in the neonatal nursing area.

\section{CONCLUSION}

The use of education strategies mediated by technology can facilitate education, improvement and updating knowledge in the field of neonatal nursing. Of all the references identified $(1,830)$, only nine were included in this review (0.5\%). The topics involved semiotics and semiology, cardiopulmonary resuscitation, basic topics of neonatal care, diagnostic reasoning and assessment of pain. The advantages of distance education described by the authors combined with shortages of educational initiatives mediated by technology found in the literature suggest the need to focus on the development and evaluation of educational resources focused on the care of newborns and their families.

\section{RESUMO}

Objetivo: Identificar recursos que favoreçam o ensino mediado por tecnologia na área da enfermagem neonatal. Método: Revisão sistemática cujas buscas foram realizadas nas bases de dados MEDLINE, LILACS e SciELO. Os títulos e os resumos foram avaliados por duas revisoras de modo independente. Resultados: Das 2.051 referências, 203 foram analisadas na íntegra, resultando na inclusão de nove estudos sobre semiotécnica e semiologia, ressuscitação cardiopulmonar, aspectos gerais de assistência neonatal, raciocínio diagnóstico e avaliação da dor. Dois artigos abordaram somente o desenvolvimento da estratégia educacional e sete descreveram processos de avaliação destas estratégias por especialistas e/ou usuários. Conclusão: $\mathrm{O}$ ensino a distância constitui importante recurso para educação, aprimoramento e atualização e particularmente para a enfermagem neonatal agregando vantagens como maior aproximação da realidade e menor exposição dos neonatos para o ensino. A escassez de iniciativas educacionais mediadas por tecnologia sugere a necessidade do desenvolvimento, avaliação e divulgação de recursos de educação voltados ao cuidado de enfermagem ao neonato e sua família.

\section{DESCRITORES}

Enfermagem Neonatal; Educação em Enfermagem; Educação a Distância; Tecnologia Educacional; Revisão.

\section{RESUMEN}

Objetivo: Identificar recursos que favorezcan la enseñanza mediada por tecnología en el área de la enfermería neonatal. Método: Revisión sistemática cuyas búsquedas se llevaron a cabo en las bases de datos MEDLINE, LILACS y SciELO. Los títulos y los resúmenes los evaluaron dos revisoras de modo independiente. Resultados: De las 2.051 referencias, 203 se analizaron íntegramente, resultando en la inclusión de nueve estudios acerca de la semiotecnia y semiología, resucitación cardiopulmonar, aspectos generales de asistencia neonatal, razonamiento diagnóstico y evaluación del dolor. Dos artículos solo abordaron el desarrollo de la estrategia educativa y siete describieron los procesos de evaluación de dichas estrategias por expertos y/o usuarios. Conclusión: La enseñanza a distancia constituye importante recurso para la educación, el perfeccionamiento y la actualización, y especialmente en lo que se refiere a la enfermería neonatal agrega ventajas como mayor aproximación a la realidad y menor exposición de los neonatos a efectos de enseñanza. La escasez de iniciativas educativas mediadas por tecnología sugiere la necesidad del desarrollo, la evaluación y divulgación de recursos de educación dirigidos al cuidado de enfermería al neonato y su familia.

\section{DESCRIPTORES}

Enfermería Neonatal; Educación en Enfermeira; Educación a Distancia; Tecnología Educacional; Revisión.

\section{REFERENCES}

1. Grossi MG, Kobayashi RM. Building a virtual environment for distance learning: an in-service educational strategy. Rev Esc Enferm USP [Internet]. 2013 [cited 2014 Jan 27];47(3):756-60. Available from: http://www.scielo.br/pdf/reeusp/v47n3/en_0080-6234-reeusp-47-3-00756. pdf

2. Rodrigues RCV, Peres HHC. Panorama brasileiro do ensino de Enfermagem On-line. Rev Esc Enferm USP. 2008;42(2):298-304.

3. Fernández Alemán JL, Carrillo de Gea JM, Rodríguez Mondéjar JJ. Effects of a competitive computer-assisted learning versus conventional teaching methods on the aquisition and retention of knowledge in medical surgical nursing students. Nurs Educ Today. 2011;31(8):866-71. 
4. Fonseca LMM, Leite AM, Mello DF, Silva MAI, Lima RAG, Scochi CGS. Tecnologia educacional em saúde: contribuições para a enfermagem pediátrica e neonatal. Esc Anna Nery Rev Enferm. 2011;15(1):190-6.

5. Gallo AM. Beyond the classroom: using technology to meet the educational needs of multigenerational perinatal nurses. J Perinat Neonatal Nurs. 2011;25(2):195-9.

6. Higgins JPT, Green S, editors. Cochrane Handbook for Systematic Reviews of Interventions. Version 5.1.0, updated March 2011 [Internet]. London: The Cochrane Collaboration; 2011 [cited 2012 Feb 20]. Available from: www.cochrane-handbook.org

7. Fonseca LMM, Góes FSN, Ferecini GM, Leite AM, Mello DF, Scochi CGS. Inovação tecnológica no ensino da semiotécnica e semiologia em enfermagem neonatal: do desenvolvimento à utilização de um software educacional Texto Contexto Enferm. 2009;18(3):542-8.

8. Fonseca LMM, Leite AM, Mello DF, Dalri MCB, Scochi CGS. Semiotics and semiology of the preterm newborn: evaluation of an educational software application. Acta Paul Enferm. 2008;21(4):543-8.

9. Fonseca LMM, Del'Angelo N, Góes FSN, Ferreia de Castro FS, De Leon CGRMP, Scochi CGS. Avaliação clínica do prematuro: opinião dos estudantes de enfermagem acerca de um software educacional. Ciênc Enferm. 2012;18(2):83-91.

10. Fonseca LMM, Aredes NDA, Leite AM, Santos CB, Lima RAG, Scochi CGS. Evaluation of an educational technology regarding clinical evaluation of preterm newborns. Rev Latino Am Enfermagem [Internet]. 2013 [cited 2014 Jan 27];21(1):363-70. Available from: http:// www.scielo.br/pdf/rlae/v21n1/v21n1a11.pdf

11. Goncalves GR, Peres HH, Rodrigues RC, Tronchin DMR, Pereira IM. Virtual educational proposal in cardiopulmonary resuscitation for the neonate care. Rev Esc Enferm USP [Internet]. 2010 [cited 2014 Jan 27];44(2):413-20. Available from: http://www.scielo.br/pdf/reeusp/ v44n2/en_25.pdf

12. Rodrigues RC, Peres HH. An educational software development proposal for nursing in neonatal cardiopulmonary resuscitation. Rev Esc Enferm USP [Internet]. 2013 [cited 2014 Jan 27];47(1):235-41. Available from: http://www.scielo.br/pdf/reeusp/v47n1/en_a30v47n1.pdf

13. Thukral A, Sasi A, Chawla D, Datta P, Wahid S, Rao S, et al. Online Neonatal Training and Orientation Programme in India (ONTOP-IN): the way forward for distance education in developing countries. J Trop Pediatr. 2012;58(6):486-90.

14. Góes FSN, Fonseca LMM, Furtado MCC, Leite AM, Scochi CGS. Evaluation of the virtual learning object "Diagnostic reasoning in nursing applied to preterm newborns". Rev Latino Am Enfermagem [Internet]. 2011 [cited 2014 Jan 27];19(4):894-901. Available from: http:// www.scielo.br/pdf/rlae/v19n4/07.pdf

15. Gibbins S, Maddalena P, Yamada J, Stevens B. Testing the satisfaction and feasibility of a computer-based teaching module in the neonatal intensive care unit. Adv Neonatal Care. 2007;7(1):43-9.

16. U.S. Department of Education; Office of Planning, Evaluation, and Policy Development Policy and Program Studies Services. Evaluation of evidence-based practices in online learning: a meta-analyses and review of online learning studies [Internet]. Washington; 2010 [cited 2014 Aug 12]. Available from: http://www2.ed.gov/rschstat/eval/tech/evidence-based-practices/finalreport.pdf

17. Berger J, Topp R, Davis L, Jones J, Stewart L. Comparison of web-based and face-to-face training concerning patient education within a hospital system. J Nurses Staff Dev. 2009;25(3):127-32.

18. Bueno M, Duarte ED, Marques RL, Freire LM, Castral T. Neonatal pain assessment program II: an innovative strategy to increase knowledge translation. Case report. Rev Dor [Internet]. 2014 [cited 2014 Aug 12];15(2):152-5. Available from: http://www.scielo.br/pdf/rdor/ v15n2/1806-0013-rdor-15-02-0152.pdf

Financial Support: Fundação de Amparo à Pesquisa do Estado de Minas

Gerais (FAPEMIG), Edital 02/2012, APQ-00370-12. 